\title{
A SUPPORT THEOREM FOR $t$-WRIGHT-CONVEX FUNCTIONS
}

\section{ANDRZEJ OLBRYŚ}

Abstract. The support theorems play a very important role in the theory of convex functions and have many consequences. In the present paper we give a necessary and sufficient conditions under which every $t$-Wright convex function has at arbitrary point a $t$-Wright affine support function.

Mathematics subject classification (2010): 39B62, 26A51.

Keywords and phrases: convexity, convex function in the Wright sense.

\section{REFERENCES}

[1] R. GER, On extension of polynomial functions, Results in Math., 26 (1994), 281-289.

[2] Z. Kominek, A continuity result on $t$-Wright convex functions, Publ. Math., 63 (2003), 213-219.

[3] Z. KomineK, Convex Functions in Linear Spaces, Prace Naukowe Uniwersytetu Śląskiego w Katowicach nr 1087, Katowice, 1989.

[4] Z. KomineK, On additive and convex functionals, Radovi Mat., 3 (1987), 267-279.

[5] H. KöNIG, On the abstract Hahn-Banach theorem due to Rodé, Aequationes Math., 34 (1987), 89-95.

[6] M. Kuczma, An introduction to the theory of functional equations and inequalities, Polish Scientific Publishers and Silesian University Press, Warszawa-Kraków-Katowice, 1985.

[7] N. KuHN, A note on $t$-convex functions, General Inequalites, 4 (1984), 269-276.

[8] K. LAJKó, On a functional equation of Alsina and Garcia-Roig, Publ. Math, 52, 3-4 (1998), 507-515.

[9] Gy. Maksa, K. Nikodem, Zs. PÁles, Result on $t$-Wright convexity, C. R. Math. Rep. Acad. Sci. Canada, 13 (1991), 274-278.

[10] J. Matkowski, On a-Wright convexity and the converse of Minkowki's inequalty, Aequationes Math., 43 (1992), 106-112.

[11] J. MatkowsKi, M. WróBel, A generalized $\alpha$-Wright convexity and related functional equation, Ann. Math. Sil. No., 10 (1996), 7-12.

[12] K. Nikodem, On the support of midconvex operators, Aequationes Math., 42 (1991), 182-189.

[13] A. OlBRyś, A characterization of $\left(t_{1}, \ldots, t_{n}\right)$-Wright affine functions, Commentationes Math., XLVII, 1 (2007), 47-56.

[14] A. OLBRYŚ, On the measurability and the Baire property of $t$-Wright convex functions, Aequationes Math., 68 (2004), 28-37.

[15] A. OLBRYŚ, Some conditions implying the continuity of $t$-Wright convex functions, Publ. Math. Debrecen, 68, 3-4 (2006), 401-418.

[16] Zs. PÁLES, Z. DARócZY, Convexity with given infinite weight sequences, Stochastica, 11, 1 (1987), $5-12$.

[17] A. W. Roberts, D. E. Varberg, Convex Functions, Academic Press, New York and London, 1973.

[18] G. RodÉ, Eine abstrakte Version des Satzes von Hahn-Banach, Arch. Math., 31 (1978).

[19] E. M. Wright, An inequality for convex functions, Amer. Math. Monthly, 61 (1954), 620-622. 